\title{
STUDENT LEARNING OF SCHOOL AGE STUDENTS IN NORTH DEVELOPMENT RPTRA WITH USED PLASTIC PROCESSING MATERIALS INTO ART-VALUED PRODUCTS
}

\author{
Popy Yuliarty, Rini Anggraini, Selamet Riadi \\ Universitas Mercu Buana Jakarta, Indonesia
}

\begin{abstract}
Recycling is the process of making used materials into new materials with the aim of preventing the occurrence of waste which can actually be useful, reducing the use of new raw materials, reducing energy use, reducing pollution and greenhouse gas emissions when compared to the process of making new goods. In this community service activity, garbage is focused on processing used plastic waste such as used bottles and used plastic spoons. This garbage can be easily found around us, for example around the campus and in the household environment and so on. This activity is a learning assistance activity for Cultural Arts and Skills subjects, namely recycling plastic type waste. Participants are students ranging from kindergarten, elementary, junior high to high school / vocational level. This activity is intended for learning assistance especially for Arts and Skills Arts subjects, where the existence of this learning assistance program is expected to help school-age students to add insight into the arts and creation and sensitivity to their environment. The purpose of this activity is to provide learning assistance and educate students to process plastic waste which causes a lot of environmental pollution.
\end{abstract}

Keywords: SBK, Processing, Plastic Waste Material

\section{PRELIMINARY}

Situation Analysis

Recycling is the process of turning used materials into new materials with the aim of preventing the presence of waste that can actually be useful, reducing the use of new raw materials, reducing energy use, reducing pollution and greenhouse gas emissions when compared to the process of making new goods. Recycling is one of the solid waste management strategies consisting of sorting, collecting, processing, distributing and manufacturing used products / materials, and the main components in modern waste management and the third part in the 4R waste hierarchy process (reduce, reuse, recycle and replace). Recyclable materials can consist of glass, plastic, paper, metal, textile and electronic waste. We often underestimate this garbage, but it can be processed into a valuable product.

In this community service activity, waste is focused on processing used plastic waste such as used bottles and used plastic spoons. This trash can easily be found around us, for example around the campus and in the household environment and so on. Unfortunately if thrown away, if burned can also cause air pollution. From this garbage, an idea emerged to use it to become a valuable product.

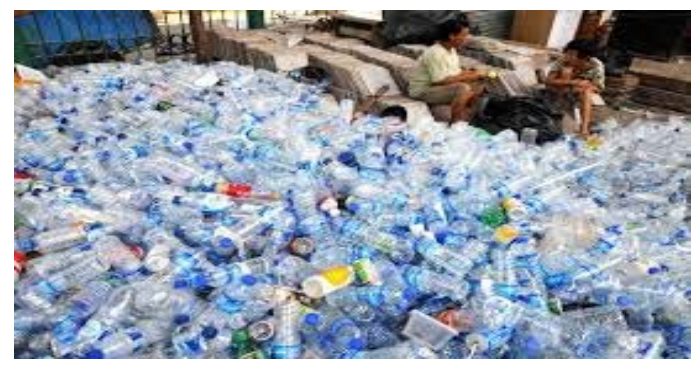

Figure 1. Below are examples of used plastic that can be recycled. 
Figure 2. Below is an example of a form of recycled plastic waste made by decorative lamps.
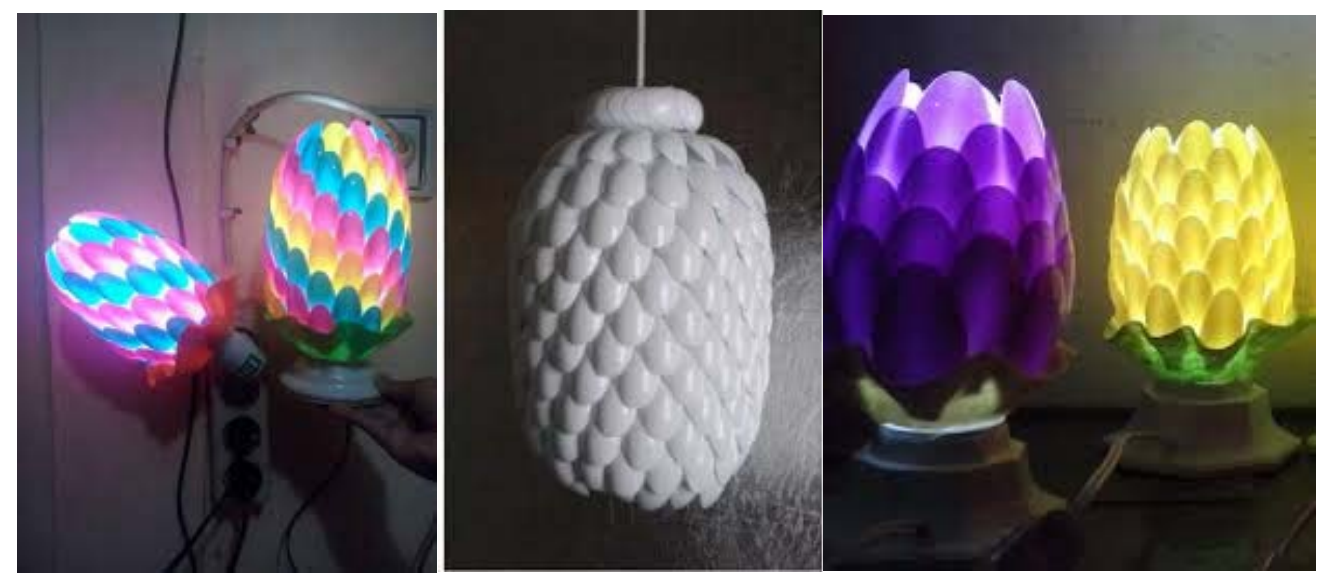

Figure 2. Examples of used plastic recycled lighting products

\section{Partner Issues}

The obvious problem is the large amount of plastic waste around us, and then an idea arises to turn it into a valuable artistic product and as an education for students, especially through this learning assistance activity. The purpose of this activity is to provide learning assistance and educate students to process plastic waste which causes a lot of environmental pollution. Plastic waste that is usually thrown away in a trash can or ended up in a junk, so with the learning assistance activities, it is expected to be able to use it to become an artistic product. To change waste into value requires special knowledge and expertise, which may not be individually studied by each individual, so this kind of mentoring activity is very useful.

\section{Target}

The target in this training is elementary, junior high and high school / vocational high school students whose implementation is carried out in RPTRA Kembangan Utara. With this assistance it is expected that the participants will have plastic waste processing skills and it is hoped that they can contribute to reducing plastic waste, recycling into valuable products, both artistic and economic value. Another mission of this activity is to educate the importance of the students' concern for the environment around them.

\section{Exodus}

Outputs from the Learning Assistance are:

1. Providing assistance in learning specifically for SBK subjects

2. The skills gained from this activity are expected to contribute to reducing plastic waste.

3. Participants gain knowledge and expertise to recycle plastic waste into valuable products.

4. The feedback from the participants on this activity in the form of filling out the questionnaire.

\section{METHOD OF IMPLEMENTATION}

\section{Nature and Form of Activities}

Learning assistance for SBK subjects is focused on recycling plastic waste into valuable products that are open to anyone, but specifically for school-age students because of this skill is expected to foster good creativity and can support SBK lessons in their respective schools. The form of the delivery method is direct material and practice. The shape of the product that will be made first is given by the trainer, then the participants follow the trainer's instructions. Participants are also given information about manufacturing techniques and the tools needed to make shapes. In addition, the trainees will be given insights about the benefits of recycling plastic waste, as well as other ideas for other types of waste. 


\section{Activity Evaluation}

Questionnaire is an information gathering technique that allows analysts to learn attitudes, beliefs, behavior, and characteristics of several key people in the organization who can be affected by the proposed system or by an existing system. By using a questionnaire, the analyst tries to measure what is found in the interview, but also to determine how broad or limited the sentiments expressed in an interview. The use of questionnaires is appropriate if:

1. Respondents (people who respond or answer questions) are far apart

2. Involve a number of people in the system project, and it is useful to know what proportion of a particular group agrees or disapproves a particular feature of the proposed system.

3. Conduct a study to find out something and want to find all opinions before the system project is given certain instructions. I

4. Want to be sure that problems in the existing system can be identified and discussed in a follow-up interview. The questionnaire that will be distributed to the respondents (in this case the trainees) is intended to find out about everything about the activities they have participated in.

\section{Work procedures}

The concept used is to attach used plastic spoons to the available containers (plastic bottles, gallons of plastic water, etc. The steps in the work procedure for the recycling of used plastic waste are as follows : used plastic spoon, used bottles, electric cables,crab, lights,plug,Scissors, Gun glue and tools

\section{RESULTS AND DISCUSSION}

To carry out community service activities, planning is needed so that the activities can run smoothly and achieve the targets. The stages in this activity can be explained as follows:

1. Phase I, namely Preparation. The preparatory phase includes meeting of the implementation team and the division of tasks, preparation of materials for training needs (purchase of production plans etc.), contacting partners to prepare for activities.

2. 2. Phase II, namely Implementation

Community service activities are carried out on:

a. Day / date: Wednesday, February 202019

b. Place: RPTRA Kembangan Utara, West Jakarta

c. Participants are school students and housewives

d. The activity was opened by the RPTRA Manager

e. The working procedure is as follows:

a) The first step, you take a plastic spoon and then cut the handle perfectly, using a cutter or razor blade, if it is difficult to use scissors, the handle leaves only a small portion of the handle of the plastic spoon, for grip. Step 1 can be seen in Figure 3.

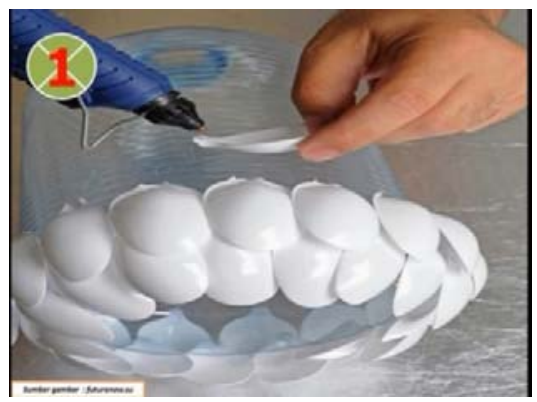

Figure 3. Step 1

b) The second step, take a large plastic bottle and then divide it according to the size you want, the top of the plastic bottle that you need the rest, you can throw away. not used. . Step 2 can be seen in Figure 4. 


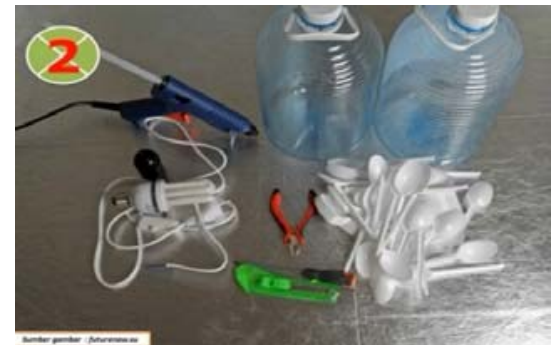

Figure 4. Step 2

c) The third step, take glue shoot, then shoot the handle of the little spoon with glue, then gently stick the spoon into the used bottle, which you had split. Remember around, starting from the bottom then continuing around until the plastic bottle was covered with a spoon perfectly. Step 3 can be seen in Figure 5

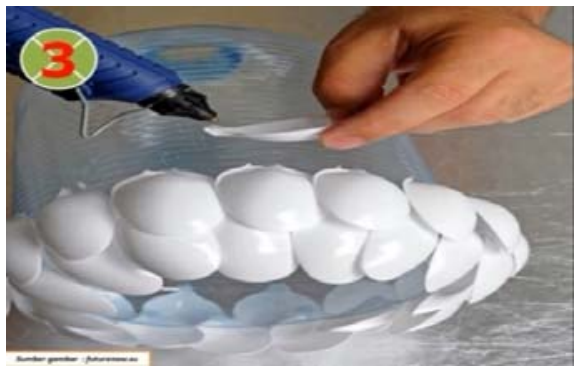

Figure 5. Step 3

d) Step four, take the cable and insert it from the bottom of the plastic bottle slowly, connect the plugs and the cage of the lamp after that, the cable length adjusts to the distance of the lamp you want to install. Step 4 can be seen in Figure 6.

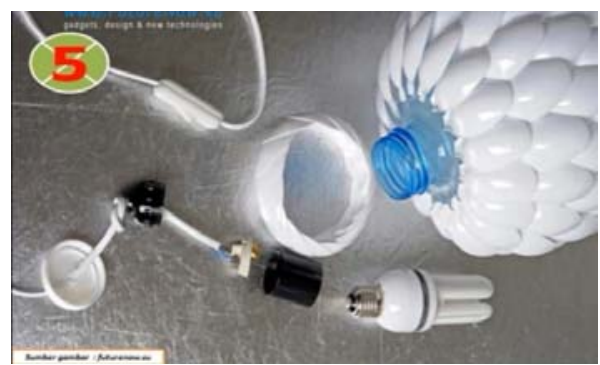

Figure 6. Step 4

The final results can be seen in the activity documentation as see in the figure 7 bellow :

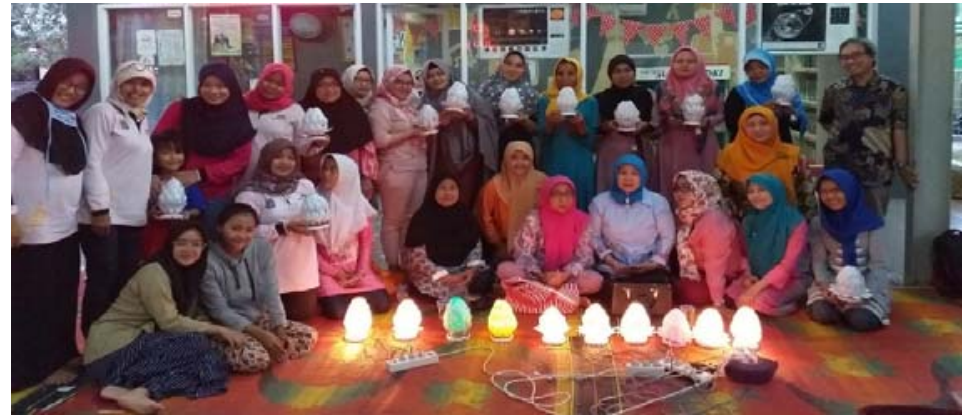

Figur 7. Final result 
3. Phase III, namely the preparation of the initial report.. Preparation of the initial report is intended to see the extent of preparation for the implementation of activities. The form is reporting that will be reviewed by a team of reviewers from PPM Mercu Buana University. The contents of this initial report include the readiness of the partners for the implementation of activities, material preparation and so on.

4. Phase IV, namely the preparation of the final report. The preparation of the final report is the end of community service activities. At this stage the activity has been completed and then an activity report must be made from the beginning to the completion of the program. At this stage an evaluation was also carried out in the form of distributing questionnaires to the training participants to see the level of success / response from the participants. Based on the recapitulation of quitionnaire, it can be concluded that in general this activity could be categorized as successful, the participants considered that this activity was very useful to support the smooth running of their tasks and hoped that in the future similar training could be given. The lowest score is on the "duration of implementation" assessment of the activity, which is an average of 3.30. Because it requires direct practice, so if you are going to hold a similar activity, then the length of time for the activity might need to be increased, so that all training participants can really practice it well.

\section{CONCLUSIONS AND RECOMMENDATIONS}

\section{Conclusion}

The conclusions that can be drawn from the community service activities are as follows:

1. Training activities have been successfully carried out on Wednesday, February 202019

2. Participants in the training are school age students and PKK administrators

3. To find out the extent of the success of this activity, the team also evaluates. Tools for evaluation using questionnaires distributed and filled directly by the participants of the activity. The results of the questionnaire showed a positive response from the participants about this activity.

\section{Suggestion}

Based on the sequence of activities to the completion of the activity, the advice we can give are:

1. Community service activities such as this get a positive response from the community, so it must continue to be developed in groups and programmed.

2. There needs to be an organized follow-up activity to see the impact on the training participants, both positive and negative, to become learning for the implementer.

3. Participants can take advantage of this skill to train the entrepreneurial spirit

\section{BIBLIOGRAPHY}

Djoko Santoso, 2013, Kewirausahaan modul pembelajaran, Direktorat Jendral Pembelajaran dan Kemahasiswaan Ditjen Pendidikan Tinggi Kementerian Pendidikan dan Kebudayaan, Jakarta

Suharyadi, Arissetyanto Nugroho, Purwanto, SK., dan Mamam Faturohman, 2007, Kewirausahaan: Membangun Usaha Sukses Sejak Usia Dini, Salemba Empat dan Universitas Mercu Buana, Jakarta

https://www.kaskus.co.id/thread/5a9800121854f779238b456f/kreatif-membuat-lampu-hias-dari-sendok-plastik/ https://ispirasidariku.blogspot.com/2016/02/hiasan-lampu-dari-sendok-bekas.html 